\title{
RUPKATHA JOURNAL
}

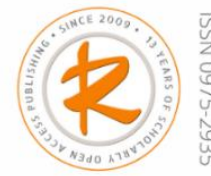

\begin{tabular}{|c|c|}
\hline \multicolumn{2}{|r|}{ About the Journal } \\
\hline Journal DOI & https://doi.org/10.21659/rupkatha \\
\hline Journal Home & www.rupkatha.com $\oslash$ \\
\hline Indexed by & Scopus $₫$ Web of Science: Emerging Sources Citation Index (ESCI) DOAJ \\
\hline Journal Metrics & CiteScore 2020: 0.2 | SJR 2020: 0.162 | SNIP 2020: 0.193 | JCI 2020: 0.50 \\
\hline \multicolumn{2}{|r|}{ About the Issue } \\
\hline Themed issue & $\begin{array}{l}\text { Volume 4, number 1, } 2022 \text { (January-March) | Contemporary East and } \\
\text { Southeast Asian Literary and Cultural Studies }\end{array}$ \\
\hline Guest Editors & Dr Jeremy de Chavez $\oslash$ \& Dr Zhang Yue, University of Macau, China \\
\hline Issue DOI & https://doi.org/10.21659/rupkatha.v14n1 \\
\hline TOC & https://rupkatha.com/v14n1.php \\
\hline Peer Review & Under the responsibility of the Guest Editors \\
\hline \multicolumn{2}{|r|}{ About the Article } \\
\hline Title & Autopoetics, Market Competence, and the Transnational Author \\
\hline Author/s & Maria Gabriela P. Martin $\otimes$ \\
\hline Affiliation & Department of English, Ateneo de Manila University, Quezon City, Philippines \\
\hline Author ID & Not available \\
\hline Funding & No funding received. Published free of any charge. \\
\hline Article DOI & https://doi.org/10.21659/rupkatha.v14n1.11 Pages: 1-8 \\
\hline Abstract & https://rupkatha.com/v14n111 \\
\hline Full-text PDF & https://rupkatha.com/V14/n1/v14n111.pdf Ø \\
\hline \multirow[t]{2}{*}{ Article History } & Abstract received: 31 March 2021 | Complete article received: 22 Oct 2021 \\
\hline & Accepted: 22 Oct 2021 | First Published: 05 February 2022 \\
\hline Article Impact & Check Dynamic Impact \\
\hline Copyright & Aesthetics Media Services \\
\hline Licensing & Creative Commons Attribution Non-Commercial 4.0 \\
\hline
\end{tabular}

This Open Access article is published under a Creative Commons Attribution Non-Commercial 4.0 International License (http://creativecommons.org/licenses/by-nc/4.0/), which permits non-commercial re-use, distribution, and reproduction in any medium, provided the original work is properly cited. For citation use the DOI. For commercial re-use, please contact editor@rupkatha.com. 
1 | Rupkatha Journal, Vol. 14, No. 1, 2022

Research Article

\title{
Autopoetics, Market Competence, and the Transnational Author
}

\author{
Maria Gabriela P. Martin
}

Department of English, Ateneo de Manila University, Quezon City, Philippines

\begin{abstract}
Although materialist analyses have critiqued the institutionalization of postcolonial studies and its emergence in global capitalism, only few have addressed the role of creative writing in standardizing migrant novelistic production to what Mark McGurl has designated as 'program fiction' whose trademark is the practice of "involuted self-reference". In filling this gap, this paper looks into Gina Apostol's writings and their reception by international audiences as exemplary of the cultural capital of program fiction. While Apostol's autofictions/ficto-criticism points to the influence of creative writing in her novels -- she studied under John Barth in the MFA program in Johns Hopkins University, this context is overlooked when metropolitan readers construe her work as postcolonial literature. I argue that Apostol's textualist renderings of Philippine history is an act of ventriloquism whose metropolitan success is a symptom of the auratic authority of postcolonial studies in the First world literary marketplace.
\end{abstract}

The institutionalization of postcolonial studies has been the subject of a debate in the field which warranted an interrogation of its genealogy and positions. Two early works that carried out this inquiry are the writings of Ella Shohat and Arif Dirlik who both noted the problematic emergence and use of postcolonial studies. In "Notes on the Postcolonial," Shohat (1992) points out that postcolonial studies, as opposed to the activism implied in 'Third World critique which it superseded, "indicates a professional prestige and theoretical aura" (p. 100) whose inchoate status, i.e., it is a catch-all term that refers to previously colonized countries and the condition of migrancy, regardless of whether people migrate by force or voluntarily, is motivated by its disinterest in positionalities that are staked in power struggles (p. 102-105). Its central term, hybridity, "fails to discriminate between diverse modalities, for example, forced assimilation, internalized self-rejection, political cooptation, social conformism, cultural mimicry, and creative transcendence" (Shohat, 1992, p. 110). Extending this critique is Arif Dirlik (1994) who in his essay "The Postcolonial Aura: Third World Criticism in the Age of Global Capitalism," claims that it is in fact global capitalism, as enabled by the presence of Third World intellectuals in the First World academe, which made possible the formation of postcolonial studies. Unlike its predecessor Third World studies, the instigations of the 'postcolonial' are unmarked by location which enables it to assume a discursive function. Dirlik (1994) considers this discursivity, which appropriated the language of poststructuralism and postmodernism, responsible for depoliticizing the term (p. 336) as it excludes the colonial from its scope (p. 337, 339). Homi Bhabha's theory, Dirlik (1994) argues, is an example: "Bhabha's work... is responsible for more than the vocabulary of postcolonialism, 
as he has proven himself to be something of a master of political mystification and of a theoretical obfuscation, of a reduction of social and political problems to psychological ones, and of the substitution of post-structuralist linguistic manipulation for historical and social explanation - all of which show up in much postcolonial writing, but rarely with the same virtuosity (and incomprehensibleness) that he brings to it" (p. 333). Its postmodern conditions of possibility, given how postmodernism inscribes the 'cultural logic of transnational capital', consigns postcolonialism to the same oversight. As Dirlik (1994) explains, "[b]y throwing the cover of culture over material relationships, as if the one had little to do with the other, such a focus diverts criticism of capitalism to the criticism of Eurocentric ideology, which not only helps postcolonialism disguise its own ideological limitation but also, ironically, provides an alibi for inequality, exploitation, and oppression in their modern guises under capitalist relationships. Thus postcolonialist argument projects upon the past the same mystification of the relationship between power and culture that is characteristic of the ideology of global capitalism of which it is a product" (p. 347). Global capitalism in this instance throws into disarray formerly stable designations such that cultural flows produce both sameness and difference: "some groups share in a common global culture regardless of location... while others are driven back into cultural legacies long thought to be residual to take refuge in cultural havens that are far apart from one another as they were the origins of modernity - even though they may be watching the same TV shows" (Dirlik, 1994, p. 353).

As attempts to capture the postcolonial through postmodern strategies, Gina Apostol's writings and their reception are symptomatic of the mystification that informs the postcolonial in the sense outlined by Shohat and Dirlik. Her metafictive novels on Philippine history promise an alternative reading of Philippine history through techniques of narrative constructionism whose point is the constructedness of narrative itself. In Insurrecto, her most recent novel published in the U.S., the non-linearity of the narrative, the use of framing devices and the insertion of a staggering number of allusions which the reader is expected to know (presumably to understand the story) imply that a successful reading of a complex text is emancipative in itself. The experience of reading the novel, as one of her interviewers puts it: "[is] like trying to solve an infinite Rubik's cube, where the only reality is authorial control... You write lines that teach us how to read the novel.... And I thank you for that" (Apostol, 2020). Apostol's response confirms her attachment to form and structure: "... one way to explain the form is that I knew I was hiding a solution to the puzzle from my reader, and I made moves and revised and created double chapters and odd dislocations because I already knew the answer to the puzzle. The beauty and, for me, absolute pleasure of writing novels is that, on the other hand, I have no idea what the puzzle will look like... There were crucial matters, though, that emerged from writing - for instance, my understanding of the locked room puzzle... which was an idea that opened up the novel's form for me" (Apostol, 2020). Although most reviews of Insurrecto praise Apostol's formal aesthetics, there are a few who found Apostol's language games distracting and pointless. Boyd Tonkin's review of the novel, for instance, acknowledges the charm of Apostol's intense writing but points out that "... [the novel's] laborious avant-garde scaffolding of films within films, scripts within scripts... exhausts more than it enlightens... Punishingly often, Apostol whisks us behind the scenes, behind the lens, to explain the function of key characters... Magsalin accuses her theory-hungry younger self of 'a surplus of academic desire'. You might say the same of Insurrecto itself, with its weakness for knowing 
postgrad in-jokes - particularly when 17 pages of end-notes rattle off a facetious routine of pseudo-scholarly gags.... And, at times, I felt that Apostol's most subversive option would have been to dump all the professor-pleasing riffs about mirrors and recurrences and tell that story as a broadly realistic slice of historical fiction to touch, to shock, and to warn" (Tonkin, 2019). The sense that the postmodern play in the novel is enervating but ultimately apolitical is echoed by Filipino critic Christian Benitez (2020) who found Insurrecto too mired in metaphor:

As a novel that attempts to 'show us the dark heart of a forgotten war that would shape the next century of Philippine and American history,' what Insurrecto ultimately offers then is a performance: the aforementioned war critically takes place less within the competing narratives in the novel, than in the struggle of reading the text itself, given its temporal and metaphoric strategies that disrupt the form, especially in its speciation in the Philippine imagination. And that such disruptions come from Apostol, a writer currently based in the United States, only doubles the violence of the Filipino disappearance to a Filipino reader: despite the desire to foreground an often neglected moment in Philippine history, the novel induces the same neglect through its impressionistic metaphorizations and aphasiac techniques, dangerously repeating to the reader the phenomenon of forgetting. (p. 113)

Apostol has responded to several of these reviews in her blog and has in fact made known her approval or displeasure. Thus, for instance, she calls out Manila Reviews reading of Gun Dealer's Daughter: A Nove/for reducing it to a "social science thesis" while describing reviewers, mostly international readers who appreciate her narrative style as "intelligent" or "smart" (Apostol, 2013). This interest in how her novels are evaluated is indicative of what Sarah Brouillette (2007) describes as the authorial strategies of postcolonial authors published in First world metropolitan centres who anticipate the reception of their work in self-conscious ways, which allows them to market their books (p. 7, 177). Extending the critiques of Shohat and Dirlik, Brouillette (2007) claims that the postcolonial novel is a commodity in the literary marketplace. These authors, she notes, "do not seek to separate themselves from the commercial or economic spheres... but to interact with various forms of politicized interpretation and reception that are imbricated with transnational culture and capital" (p. 74). Postcolonial literature has thus become a brand with its marketable characteristics: "it is English-language fiction; it is relatively 'sophisticated' or 'complex' and often anti-realist; it is politically-liberal and suspicious of nationalism; it uses a language of exile, hybridity, and 'mongrel' subjectivity" (Brouillette, 2007, 61). Brouillette (2007) argues that the taste for such books is generated by "cosmopolitan, elite readers of English-language literary fiction" who comprise the niche audiences that transnational publishing caters to (p. 56). This process lays bare Gina Apostol's arrogation of 'postcolonial' to create a niche for her novels. Her essays and reviews of her books, for instance, readily apply the term to her writing in order to underscore its political relevance in a way that preempts other interpretations. In "Borges, Politics, and the Postcolonial," for instance, Apostol proposes the postcolonial as a term that reconciles her politics as a writer with that of Borges. She calls Borges's essay "The Argentine Writer and Tradition," which she considers an exemplary polemic against essentialism, "a classic in deconstructive postcolonial thought, before Gayatri Spivak, before Homi Bhabha" (Apostol, 2013).

Despite Apostol's claims about postcolonial theory, one can gain a more critical understanding of her novelistic production if one situates it in the context of creative writing as it 
became institutionalized in the U.S in the 60s. I would argue that her predilection for postmodern constructionism is influenced by her training in the MFA program in Johns Hopkins University under John Barth, a celebrated American postmodern author. Apostol sent the first sections of Bibliolepsy to Barth as part of her application to the program and her first novel Bibliolepsy is her MFA thesis. Although Apostol doesn't explicitly attribute her novels to her creative writing background, she does acknowledge the influence of Vladimir Nabokov and Jorge Luis Borges in her writing. The premise of Nabokov's Pale Fire and that of The Revolution According to Raymundo Mata are strikingly similar. Both involve a purloined manuscript and the postmodern trope of the puzzle which self-consciously undermines scholarly issues of authorship and attribution. Like Professor Charles Kinbote, the thief of John Shade's long poem, who writes himself into the work while annotating it, Raymundo Mata might or might not have stolen and tampered with Jose Rizal's third novel Makamisa. Kinbote, an academic who distorts Shade's work in making it about himself, is transposed onto three figures in Apostol's novel: a translator (Mimi Magsalin), an editor (Estrella Espejo), and psychoanalytic critic (Diwata Drake) who all misread Mata's diary to dispossess it of a singular meaning. McGurl, in The Program Era: Postwar Fiction and the Rise of Creative Writing, describes the figure of Nabokov as indicative of the centrality of aesthetic experience in the development of creative writing programs as it became affiliated with the university. Although Nabokov taught creative writing, he was not a product of any writing program. Nevertheless, McGurl (2009) considers his eclectic views about artistry as expressive of what programmatic fiction would later on prioritize as "autonomous self-creation" (p. 3). For Nabokov the purity of art can only be preserved by refusing all manner of daily distractions such as work and by spurning "[t]he study of the sociological or political impact of literature" which is meant "for those who are by temperament or education immune to the aesthetic vibrancy of authentic literature, for those who do not experience the tell-tale tingle between the shoulder blades" (as cited in McGurl, 2009, p. 9). The preservation of 'exalted' experience, away from social contexts, would be articulated in what Donald Barthelme coined as "Not-Knowing," an imperative to maintain "the aura of literature." This valorization of aesthetic experience, ultimately the author's, is consequently a rationale for Nabokov's penchant for writing novels "that uncannily refer to himself" (McGurl, 2009, p. 9). As noted by Arnold Appel, a biographer of Nabokov, this "obsessive reflexivity of Nabokov's work" is "an aesthetic of 'involution'" (as cited in McGurl, 2009, p. 9), compatible with postwar culture's encoding of modernist reflexivity in the style of metafiction. These authorial concerns clarify Nabokov's pronouncements that he only writes for himself "in multiplicate" (as cited in McGurl, 2009, p. 5), a logic that Apostol has used in her writing; that "[a]rtistic originality has only its own self to copy"; and that a book's style, regardless of its topic, "constitutes an intrinsic component or characteristic of the author's personality" which "remains diffused through the book so that his very absence becomes a kind of radiant presence" while suggesting that the act of writing is the unfolding of his "serial selves" (as cited in McGurl, 2009, p. 11). Nabokov's writings about the self, McGurl (2009) explains, takes on "an obsessive self-reflexivity [that] produces an intimidating effect of hyper-cleverness [such that] everyone in the novels, including the person at the source of their utterance, is subject to an ongoing process of figural doubling, division, rotation, and reversal - a sequencing of formal-ontological differentiation along axes of identity" (p. 10). Because of these qualities, McGurl claims that his novels and authorial statements are emblematic of a performative self-establishment which informs programmatic fiction in its emphasis on "write what you know," a dictum that elevates 
and transforms the uniqueness of experience. McGurl's reading of Pale Fire demonstrates the author's wish-fulfillment that enables him to write about his own predicament in an impersonal and elliptical manner.

Using his own preferred idiom of fairy-tale and romance, it could be described as a way for a king-in-exile to recover his country and reassert his rule on a linguistic-aesthetic plane. Nabokov's lifelong attraction - sometimes ironic, sometimes not - to the traditional romance motif of unrecognized royalty is fabulously evident in Pale Fire, where the deranged Kinbote has (at least in his own mind) been chased from the throne of the nation of Zembla to his ignominious dwelling at Wordsworth College, U.S.A. As the descendant of Russian nobility cut off from the vast country estate he roamed as a child, and from the language, Russian, in which he first made his name as a novelist, Nabokov had a more plausible biographical claim to a fantasy of royal restoration-in-language than most. But even for him this was essentially metaphorical, a way of imagining a life of uncompromised and exalted individuality.... Instead of testifying to a permanent condition of disadvantage in the face of physical necessity, or the relentless humiliations exacted by social institutions, or to a perpetual process of wounding at the hands of history, "personal experience" is redeemed in this manner as a proud and vibrantly reflexive presence. (McGurl, 2009, p. 1112)

These adumbrations of personal experience, more than postcolonial theory, indexes the function of self-reflexivity in Apostol's novels and her paratextual statements. The significant difference is that Apostol's redemption of personal experience conduces to unmediated textual expressions of postcolonial hybridity and ambivalence. In an interview about Insurrecto, for instance, Apostol explains her splitness as a subject: "this doubleness, for me, is existential - it's a human thing.... [s]o many of Borges's stories are about doubleness... Some of Vladimir Nabokov's work like Laughter in the Dark... I am not interested in identity as sadness about my doubleness" (Apostol, 2013). In her Foreword to Ulirat: Best Contemporary Stories in Translation from the Philippines, she discloses the significance of linguistic multiplicity for Filipinos: "As a Waray child on vacation in Cebu, clutching my Christmas money, I'd calculate from the mood of the salesgirl at Gaisano which other language to use since she wouldn't know my own - my funny Cebuano? my stilted Tagalog? my annoying English? I knew if I chose the wrong mediating language she'd hand me the Hello Kitty barrette with the disgust of a sophisticate whose tongue ruled at Colón Street in Cebu" (Apostol, 2021). Here and in other paratexts Apostol defines the postcolonial as a condition of duality which is nonetheless installed in the identity of the author. That hybridity and doubleness are fulfilled in and performed by the figure of a migrant author, whose novels are regarded as postcolonial representations of Philippine history by a metropolitan First world public, makes evident the political vacuity and ahistorical aims of postcolonial studies. As Dirlik (1994) points out, the importance given to subjectivity in postcolonial studies obscures "the world outside of the subject," "a global condition which appears at best as a projection onto the world of postcolonial subjectivity and epistemology - a discursive constitution of the world... in accordance with the constitution of the postcolonial subject, much as it had been constituted earlier by the epistemologies [e.g., Orientalism] that are the object of postcolonial criticism" ( $p$. 336). Given its abstract representation of the subject, postcolonial is at best a discourse constructed through "the self-image of" Third World intellectuals who are now in the First World 
and is thus "an expression of not so much of agony over identity, as it often appears, but of newfound power" (Dirlik, 1994, p. 339). The complicity between postcolonial studies and global capitalism has effected the commodification of postcolonial novels as Brouillette has pointed out. Thus while Apostol's postmodern fictions offer a non-linear construction, one that as Apostol repeatedly claims suits 'her view of reality or history' (e.g. doubleness), its constant and automatic deployment reproduces an essentialized identity in the figure of the reader. As a consequence of her regurgitating postmodern tropes and academic puns, her novels have become a matter of formula, a branding which nevertheless appeals to her metropolitan readers. Moreover, the nonreflexive employment of self-conscious techniques in her novels tend to annul a grounding of the subject or event in its historical specificity. Dirlik's assertions regarding the power of the postcolonial intellectual is thus exemplified in Apostol's insistence on multiplicity as a means of redressing or exposing the invisibility wrought by colonial epistemic violence. Given Shohat and Dirlik's claims that the postcolonial began "when Third World intellectuals have arrived in the First World academe (Dirlik, 1994, p. 329), it is not surprising that Apostol's novels are given more positive reviews in the Anglo-Am literary marketplace.

This sameness is not only observable in Apostol's novels but is in fact evident in the production of postcolonial literature in general. Neil Lazarus (2011) has deplored the homogenous quality of postcolonial literature which he claims reflects the apolitical status of postcolonial studies as a field. Its privileging of "migrancy, liminality, hybridity... an aversion to dialectics... and a refusal of an antagonistic or struggle-based model of politics" (p. 21) has produced a reductive set of qualifications. Postcolonial literature, he observes, is only interested in replicating what the critical reception of Salman Rushdie's novels has privileged, namely "the instability and indeterminacy of social identity, the volatility and perspectivalism of truth, the narratorial constructedness of history, the ineluctable subjectivism of memory and experience, the violence implicit in the universalist discourse of the nation, the corresponding need to centre analysis on the notions of migrancy, hybridity, diaspora, 'in-betweenness', translation... and so on" (Lazarus, 2011 , p. 22). Lazarus notes that this uniformity also determines the kind of critical inquiry that a postcolonial reading is required to perform which reproduces questions answerable by the same set of concerns. The tautological nature of this particular analysis is such that "all that is required of the texts evoked is that they permit - which is to say not actively disallow - a certain, very specific and very restricted kind of reading to be staged through reference to them" (Lazarus, 2011 p. 22). These qualities are evident as well in what Timothy Brennan has identified as "new cosmopolitan writing" whose narrative production is designed in such a way to attract a postcolonial reading and have about them the "feel of ready-mades" (p. 23). This kind of reading also manifests in several postcolonial anthologies that group in a mindless manner authors whose persuasions or self-awareness are not identifiably postcolonial. Conversely, Lazarus claims that postcolonial literary studies too easily dismiss works which do not correspond to these "received categories and conventions" and, echoing Brouillete (2007) points out that "it is much more likely to register the presence of writers who adopt generic and modal conventions readily assimilable by Euro-American readers than of writers who root their work in other conventions" (p. 26).

Lazarus's observation that postcolonial studies is interested only in a reading which validates its categories explains Apostol's emphasis on reading as an essential component of the postcolonial perspective in her novels. In "Borges, Politics, and the Postcolonial," she draws 
attention to the significance of reading in activating a postcolonial agency: "Borges's writing was always, to some degree, a creative form of reading". Pointing to her identity as a postcolonial author, she writes: "It is impossible to perceive who I am except through acts of serial reading". In another iteration, she claims we can all learn from Borges "an art of reading that makes meaning out of the mess of our modern world" (Apostol, 2013).

Apostol's prescriptions about reading which are tied to a postcolonial textual dynamic are instructive examples of Pierre Bourdieu's point that the academic market has professionalized how we read. In "Reading Literature/Culture: A Translation of 'Reading as a Cultural Practice,'" Bourdieu (2002) identifies reading as a type of cultural consumption, whose history refers to the same conditions that produce the reader (p. 665). Rejecting the idea that reading is a universal and neutral disposition while asserting that it is vulnerable to disciplinary mechanisms, he claims that "[o]ne element of being a reader is the elision of the question why one reads, whether reading is self-evident, and whether there is a need to read". To historicize reading, one "should examine the conditions in which this need is produced" (Bourdieu, 2002, p. 668). For Bourdieu this production takes place in a cultural field, of which postcolonial studies is an example, where "prejudicial knowledge," or 'right readings' are conditioned and generated by the shared habitus between authors and their readers. This demystification reveals "a correlation between educational level and the quantity and quality of texts read," which is to be expected since reading "is directly taught by the educational system" and demonstrates that one engages a text because there exists "a market in which to trade readings" (Bourdieu, 2002, p. 667, 668). As an effect, academic reading, in its propensity to naturalize 'correct interpretations', assumes symbolic power by which other possible decodings are considered faulty or inadequate (Bourdieu, 2002, p. 671). This logic lays bare the currency of postcolonial studies in metropolitan locations, which recalls Dirlik's critique of the term. Bourdieu (2002) argues that, in a manner that recalls the Apostol's asseverations about postcolonial/double vision, reading is "the site of the assertion of power, and often the context for the struggles of power" (p. 662).

\section{Declaration of Conflict of Interests}

The author(s) declared no potential conflicts of interest.

\section{Funding}

No funding has been received for the publication of this article. It is published free of any charge.

\section{References}

Apostol, G. (2021). "A Speech of One's Own." Evergreen Review. https://evergreenreview.com/read/aspeech-of-ones-own/

Apostol, G. (2014, Feb 7). "Reading Novels: A Novelist's View." https://ginaapostol.wordpress.com/2014/02/20/reading-novels-a-novelists-view/

Apostol, G. (2013, Aug 18). "Borges, Politics, and the Postcolonial." Los Angeles Review of Books. https://lareviewofbooks.org/article/borges-politics-and-the-postcolonial/ 
8 Autopoetics, Market Competence, and the Transnational Author

Apostol, G. (2020, Feb). "In Conversation: Preti Taneja and Gina Apostol." The White Review. https://www.thewhitereview.org/feature/preti-taneja-and-gina-apostol/

Benitez, C. (2020) "Book review: Gina Apostol, Insurrecto: A Nove/ and Dominic Sy, A Natural History of Empire: Stories." SARE, 57 (2). pp.110-114.

Brouillette, S. (2007). Postcolonial Writers in the Global Literary Marketplace. NY: Palgrave Macmillan.

Bourdieu, P. (2002). "Reading as Cultural Practice". Trans. Todd Reeser. Resources in Stylistics, and Literary Analysis, 36 (4). pp. 659-675.

Dirlik, A. (1994). "The Postcolonial Aura: Third World Criticism in the Age of Global Capitalism". Critical Inquiry, 20 (2). pp. 328-356.

Lazarus, N. (2011). The Postcolonial Unconscious. Cambridge University Press.

McGurl, M. (2009). The Program Era: Postwar Fiction and the Rise of Creative Writing. Harvard UP.

Shohat, E. (1992). "Notes on the 'Postcolonial'". Social Text no. 31/32. pp. 99-113.

Tonkin, B. (2019, July 14) "Gina Apostol: Insurrecto review - a treacherous archipelago of stories."

Theartsdesk.com. https://theartsdesk.com/books/gina-apostol-insurrecto-review-\%E2\%80\%93treacherous-archipelago-stories

\section{Author's bio-note}

Maria Gabriela P. Martin teaches at the Ateneo de Manila University where she finished AB Humanities and MA in Literary/Cultural Studies. Aside from teaching core curricular English and literature classes, she has taught elective courses in Western Literature. Her research interest engages the intersection of Marxist critique and genre studies, focusing on the works of Mikhail Bakhtin and Fredric Jameson. 